\title{
Introduction to Special Issue: Real-World Justice and International Migration
}

\section{Real-World Problems in International Migration}

The movement and displacement of people across state boundaries - in particular, of people seeking escape from severe forms of political, economic, or environmental threat or hardship - now occurs on a scale unprecedented in previous eras of international politics. Migrants and asylum seekers confront states and international institutions with multiple political demands ranging from temporary humanitarian assistance through to permanent access to the full and equal rights of political citizenship. As a result, governments and other international decision-makers are routinely challenged with complex normative dilemmas concerning what should count as just responses to the demands of migrant populations.

Political theorists have responded to these challenges with vigorous debates about the justice of various institutional and policy approaches to managing international migration. To date, these theoretical debates have been framed predominantly in 'idealtheoretic' terms, concerned with identifying the principles that should regulate migration within an ideally just liberal-national, international, or cosmopolitan-global society (Valentini, 2012). Key controversies within these discussions have been concerned with: what kind of migration controls are compatible with a cosmopolitan view of global justice (Christiano, 2008; Brock, 2009); whether state borders should in principle be open or closed (Carens, 1987, 2013); whether border controls are coercive, and the conditions under which border coercion can be just (Abizadeh, 2008; Miller 2010); and what moral rights to control territory or to move across it freely individuals and self-determining political communities possess (Fine, 2013; Nine, 2008; Risse, 2008; Stilz, 2011; Wellman, 2008).

One striking feature of these debates, however, is the stark disparity between the principal topics of theoretical controversy, on the one hand, and the animating sources of political controversy within the real national and international publics grappling with problems of migration governance, on the other. This disparity arises not merely from 
the familiar distortion of principled positions within real political debates through their instrumental deployment towards various strategic ends: to distract electorates, to externalize public emotions of fear or resentment, to scapegoat vulnerable populations, to forge domestic solidarities or identities, to wedge political opponents, or to cast strong personas of political leadership within salient constituencies. While such strategic distortions of principled arguments are pervasive, they do not have clear implications for normative analysis of justice in international migration - beyond their implications for considerations about the feasibility of various political ideals. There are, however, other important sources of divergence between theoretical and real political controversies with more direct implications for normative analysis. Here we are concerned with two sources of divergence that have particular significance for the way that that the normative analysis of justice in international migration is to be conceptually framed and methodologically developed.

First, there is a sharp disconnect between theoretical and real political debates in the framing of those concrete problems on which normative analysis is purported to offer guidance. This disconnect begins with divergent portrayals of the central phenomenon of migration (and its institutional regulation) that is the subject of controversy. In idealtheoretic liberal theoretical literatures, migration control is commonly portrayed straightforwardly as a practice that occurs at the territorial or political interface between bounded sovereign institutions or national communities - whether through the exercise of coercion at territorial borders, or through collective acts by political associations to exclude or deny political membership. Real political controversies, in contrast, respond to problems arising from the political dynamics of a much more complex set of institutional relationships and governance practices associated with the phenomenon of international migration; in these, simple forms of territorial sovereignty and political exclusion play more ambiguous roles.

In many cases of real migration practice, for instance, states' migration policies and operations reflect not the assertion of territorial sovereignty, but rather the disaggregation and dispersion of sovereign power - for example, through the outsourcing of a range of border control powers and responsibilities to other states and private companies, as pursued by Australia and EU states in recent years (Boswell, 2003; Haddad, 2008; Mountz, 2008). Other border control measures involve not the 
expansion of states' territorial frontiers, but rather their legislative deflation - for example, through Australia's legislative excision of certain island territories from its own sovereign migration zone, as a means of securing compliance with international refugee law while refusing to process asylum applications by boat arrivals to those territories (Fox, 2013). More broadly, states' management of migrant populations institutionalizes relationships not only of political exclusion, but also variously of interrogation, detention, deportation, deterrence, and similar institutionally mediated forms of political engagement (Brouwer and Kumin, 2003; Howard 2003).

The political problems raised by international migration thus pose practical dilemmas concerning management of highly complex institutionalized relationships between states and migrant populations. Given their complex and dynamic character, these cannot be adequately captured in terms of the simple philosophical dichotomies of openness/closure or inclusion/exclusion that frame many established theoretical debates.

A second sharp disconnect between ideal theories of migration and real political controversies arises in the character of the opposing justificatory reasons that clash within these respective migration debates, and are regarded by participants as salient grounds for settling the controversies. Theoretical analysis of justice in migration has so far been dominated by a distributive model of justice, in which the normative reasons advanced in support of particular migration-control institutions take the form of principled conceptions of individuals' moral claims to some settled range of social goods (such as political membership, or territory and its material resources) that are understood to be distributed through these institutions. In real political debates, however, arguments extend beyond advancing principled positions about how some agreed set of social goods should be distributed; commonly, political arguments focus instead on how the character of these goods should be understood in the first place, and the identities of those with special claims to them. In other words, much justificatory reasoning within migration debates is directed towards defending rival framings of what goods are at stake and for whom in the institutional regulation of international migration, rather than rival moral principles for settling the moral rights of particular individuals or communities in relation to these goods. 
One clear example of this can be found in the persistent contestation surrounding the securitization of migration governance within many states, whereby political disputants work to emphasize or de-emphasize the impact of migration regimes on important security interests (Hyndman and McDonald, 2001). Similar forms of contestation occur in some states in relation to the criminalization of irregular migrants, including asylum seekers. Here much political capital is invested in disputes over the language and labels used to categorize the individuals and behaviours that are targets for regulatory intervention - illustrated for example by a controversial recent ministerial directive in Australia that immigration department staff must always refer to irregular migrants arriving by boat as 'illegal maritime arrivals' instead of 'asylum seekers' or 'refugees' (Hall, 2013). More broadly, the category of refugee has particular political salience in migration debates, in terms of its role in framing and institutionally positioning the claims of particular individuals or groups in relation to normative principles of justice (Gibney, 2004). As a result, there is significant ongoing dispute over how this political identity should be defined, and what range of special normative principles should apply in distributing rights and duties of justice in relation to those who are identified as falling within this category.

Beyond such disputes about the character of the goods and social identities that should serve as the objects and subjects of distribution within a distributive model of justice, other political arguments challenge this distributive framing itself, as a basis for grappling with problems of migration justice. Within many democratic states, in particular, problems of international migration governance raise serious dilemmas of political as well as distributive justice (Macdonald and Ronzoni, 2012). Some of the most significant controversies about political justice in international migration concern the character of public power and demands of legitimacy in international border governance; more specifically, they concern which institutional standards of transparency, democratic oversight, public accountability, judicial scrutiny, and so on should apply to the distinctive forms of public power that are exercised in migrationcontrol policy-making, operations, and administration.

\section{Connecting Theories of Justice to Real-World Political Problems}

These examples illustrate how political disputes surrounding justice in international migration extend beyond concern with abstract moral arguments about the content of 
the distributive rights and duties of individuals or communities. They extend further into highly contextual interpretive political arguments concerning the way that migration problems should be positioned in relation to a range of social and institutional categories that are central to the normative analysis of distributive and political justice, but intelligible only in relation to particular concrete and differentiated modes of international governance. If normative theories of justice are to be action-guiding in relation to migration governance - offering principled guidance on the resolution of dilemmas confronted by real political actors in real practical predicaments - then we need to develop theoretical approaches to the analysis of international justice that is adequately responsive to the concrete specificities of the problems political actors confront, on the terms that political actors understand and recognize these problems.

There is nothing new, of course, in the general observation that there are limitations to the forms of practical guidance that ideal-theoretic approaches to the normative theory of justice can offer on many real political dilemmas - including those surrounding migration (Carens, 1996). In recent philosophical debates, dissatisfaction with this gap between normative theory and political practice has motivated growing literatures on 'non-ideal' theoretical approaches (Simmons, 2010; Stemplowska, 2008). These approaches share with ideal theory a principled commitment to some moral ideal of a just society, but depart from ideal theory by adjusting some of its idealized assumptions to achieve greater responsiveness to empirical facts about the motivations and circumstances of real political actors. Given their continuing orientation towards moral ideals, non-ideal theoretical approaches are most useful for addressing questions about what justice requires when ideals are presently unattainable, yet still intelligible as aspirational targets for political action in the sense that some clear transformative pathway towards the ideal can be identified (Sen, 2006).

Non-ideal approaches provide fewer analytic resources, however, for guiding action in relation to complex and contextual institutional dilemmas of the kind outlined above such as those concerning the political legitimacy of regional migration governance institutions, or the just treatment of irregular migrants intercepted in transit on the high seas, or relegated to migration detention facilities while their asylum claims are processed. This is because these political problems are framed not as questions about how to get closer to ideals, but rather as questions about how to get by and act well in a 
political environment so remote from moral ideals that transformative pathways towards them are indeterminate. Under these circumstances, theoretical constructions of ideally just societies are not intelligible even as aspirational targets for political action, and as such are unable by themselves to guide real political judgment and decision-making. While the project of non-ideal theory certainly helps to create in-principle conceptual space for placing problems of this kind on the intellectual agenda of political theory, it does not in itself supply the substantive theoretical resources needed to resolve them.

One promising place to look for the requisite theoretical resources is within a burgeoning new literature on so-called 'realism' in political theory (Galston, 2010; Geuss, 2008; Philp, 2010; Sleat 2014, Williams 2005). Like non-ideal theory, 'realist' political theory is aimed at developing tools for normative analysis that are more responsive to the concrete particularities of real political dilemmas than established ideal-theoretic approaches. But whereas non-ideal theory retains a normative grounding in moral ideals of justice (albeit with some concessions to real empirical constraints), 'realist' approaches make a fuller break from ideal theories. In making this break, they seek alternative groundings for normative analysis by developing substantive arguments at methodological and empirical as well as moral levels of analysis. These include most significantly: arguments about the character of political 'normativity' and its relationship to morality; empirical claims about the circumstances and motivational logics of political life - such as those commonly associated with a 'Realpolitik' tradition of realist thought; and normative claims about the special values and regulative principles - such as political 'order' and 'legitimacy' - that should guide action within this distinctive political domain (Rossi and Sleat, 2014). Additionally, there is a burgeoning literature evaluating the epistemological constitution of 'the real' from which realism derives so much of its rhetorical power (Little, 2015).

The contributions to this special issue all explore the potential of this broad family of theoretical approaches to generate new insights on concrete political and institutional dilemmas concerning justice in international migration. In doing so, none of the authors is strongly committed to the 'realist' label as a conceptual umbrella for these inquiries. To the extent that invoking this label may risk diverting analytic energies away from the complex particularities of real political problems - directing them instead towards elaborating the conceptual themes of a nominal 'realist' school or tradition - we may be 
better off avoiding it. The 'realist' label can be useful, on the other hand, to the extent that it draws into constructive dialogue a range of otherwise independent avenues of inquiry that share a central aim: developing normative theories better able to guide political action in relation to real social and institutional dilemmas. In order to connect with this established conversation, while resisting any of the reductive ascriptions sometimes associated with a realist 'school' or 'tradition', we characterize our collective project here as a search for principles of 'real-world' justice in migration.

There are three key dimensions in which the 'real-world' theoretical approaches developed in this collection of papers connect up with important themes in the wider theoretical literature on political 'realism'. First, the papers in this collection deploy a methodological strategy that can be broadly described as problem-centred. By problemcentred, we mean a theoretical strategy that formulates and justifies normative principles for political action and institutions through direct and systematic engagement with real political predicaments and dilemmas, as these are understood by the real political actors whom the theory aims to guide. Problem-centred analysis begins by identifying - at variable levels of theoretical generality - concrete problem situations, defined in terms of: (a) a set of circumstances that are in some way problematic or unsatisfactory for the political actors confronting them; and (b) some process of inquiry aimed at identifying principles or strategies for action to navigate pathways out of these predicaments.

There are many different ways of developing the idea of problem-centred theory, and elaborating the methodologies associated with it. The theorist perhaps best known for problem-centred inquiry is the pragmatist John Dewey, who argued that philosophical inquiry and democratic politics, when well executed, should both be understood as efforts to solve the problems of people and their societies, as these problems are concretely experienced and understood (Dewey, 2012, 1925). This problem-centred pragmatist approach shares much in common with what David Miller has called 'contextualism' in normative theory, which holds more generally that principles of justice must always be justified with reference to the full - inevitably complex and messy - set of social facts in which human beings act and their political institutions function. Political theory should be contextualist in this sense, as Miller argues, because theory that is unresponsive to facts about people's real beliefs and circumstances 
'cannot respond constructively to changes that are occurring in the world outside, so it has to retreat to a position of pure, principled opposition' (Miller, 2013: 4).

Another well-known theoretical strategy oriented towards the diagnosis and conceptualization of political problems is associated with Foucault's elusive idea of 'problematization' (Foucault, 1991). This approach involves definitional questions concerning the means of establishing particular social phenomena as 'problems' and the implications that they generate for conceptualizations of political action. This notion of problematization highlights the boundaries that are established around potential courses of political action to solve the 'problem' in the discursive framing of something as a particular problem in the first place. This challenges the general idea that normative theorizing should proceed from the identification of a concrete problem or predicament of the kind that is sometimes invoked by theorists working within broadly rationalist and contractarian traditions - for example in the problem-centred analysis of the political value of international institutional legitimacy developed by Buchanan and Keohane (2006). Within those literatures that self-identify as 'realist' in orientation, the idea of problem-centred normative analysis is similarly developed through an exploration of the value of political legitimacy - in this latter case by Bernard Williams (2005). He argues that normative political theory must begin with the 'first political problem' of achieving order understood as security from violence and fear, and that the first task for political institutions must be to supply such order, subject to what he calls a 'basic legitimation demand' (Williams, 2005).

A focus on the value of political legitimacy, more broadly, provides a second key point of contact between recent 'realist' theoretical scholarship and several of the papers in this collection. Under the influence of Williams, realists have developed a range of arguments for viewing legitimacy as in some sense an autonomously political value that cannot be adequately understood within the conceptual and justificatory frameworks of philosophical 'moralism' (Bavister-Gould, 2013; Ceva and Rossi, 2012; Erman and Moller, 2013; Hall, 2013, Sigwart, 2013, Sleat, 2014). The questions of what exactly legitimacy is, what relationship it has to justice, and what kind of 'normativity' its principles possess, remain subjects of ongoing dispute - both among realists, and with those 'moralists' who insist that the value of legitimacy can be internalized within and subordinated to morally grounded theories of justice. Although the papers in this 
collection do not aim to survey or resolve these theoretical disputes about legitimacy, the recognition of legitimacy as an autonomously political value, depending in important ways on real political agency, motivations, beliefs, and institutions, plays a significant role in the framing of some of the contributions.

The third key connection between the new theoretical 'realism' and this group of papers is the common view that political analysis can sustain meaningful contact with real political problems and circumstances, without abandoning a commitment to work that is normative and critical. This variety of realism is thus importantly distinct from the familiar International Relations 'realism', or 'Realpolitik', positing a political world dominated by self-interested strategic action. While the new theoretical realism shares with IR realism an opposition to utopian forms of moral prescription in political theory, it nonetheless adopts an explicitly critical and normative orientation, and aims to develop methodologies for evaluation and prescription of political action that take account of the reality of a full range of political motivations, including solidarity, compassion, and a sense of justice alongside egoistic pursuit of power, prestige, and material enrichment. Adopting an approach of this general kind, the papers in this collection eschew both the moral disengagement of IR Realpolitik, and the utopian or 'ideal-theoretic' preoccupation with elaborating idealized institutional blueprints and principles of justice in migration practices that remain remote from the controversies and possibilities inherent in real-world political contexts. Instead, they engage directly with real political debates and dilemmas and the rich range of real political motivations and commitments that these embody.

\section{Six Arguments About Real-World Justice and International Migration}

Unified by these three theoretical elements, the six papers in this collection pursue inquiries into the conditions for real-world justice in migration through a focus on problems at both conceptual and policy levels. The first three papers in the collection, by David Miller, Terry Macdonald, and Adrian Little, analyze three fundamental political concepts that are widely used to frame normative analysis of international migration: justice, legitimacy, and borders, respectively. A central aim of these analyses is to develop framing concepts that fit more closely than ideal-theoretical models with the real complexities of migration practices, institutions, and problems, and thereby to assist in the articulation of action-guiding theoretical agendas on this topic. 
The remaining three papers, by Matthew Gibney, Patti Lenard, and Robyn Eckersley, focus on specific policy problems and normative dilemmas that arise for states seeking to manage and govern international migration under prevailing real-world circumstances and constraints. These papers all proceed from the common premise that real immigration policy dilemmas cannot be adequately characterized in terms of stylized abstract choices such as those between political 'inclusion' and 'exclusion', or border 'openness' and closure', or assessed with reference to very abstract and general principles of justice. Rather, real dilemmas are framed using institutionally and historically specific concepts (such as that of a refugee), and with reference to institutionally and contextually variable normative values and principles that are derived through real political debates and institutions, rather than through abstract philosophical reflection. From this premise, these papers examine three such important and specific policy dilemmas, concerning respectively: just principles for the allocation of state responsibility for refugee protection; just principles for regulating state practices of deportation; and how to conceptualize the status and evaluate the justice of political claims to international protection by so-called 'climate refugees'.

\section{References}

Abizadeh A (2008) Democratic theory and border coercion: No right to unilaterally control your own borders. Political Theory 36(1): 37-65.

Bavister-Gould A (2013) Bernard Williams: Political realism and the limits of legitimacy. European Journal of Philosophy 21(4): 593-610.

Boswell C (2003) The 'external dimension' of EU immigration and asylum policy. International Affairs 79(3): 619-638.

Brock G (2009) Global justice: a cosmopolitan account. Oxford: Oxford University Press.

Brouwer A and Kumin J (2003) Interception and asylum: When migration control and human rights collide. Refuge 21(4): 6-24.

Carens JH (1987) Aliens and citizens: the case for open borders. The Review of Politics 49(2): 251-273.

Carens JH (1996) Realistic and idealistic approaches to the ethics of migration. International Migration Review 30(1): 156-170.

Carens JH (2013) The ethics of immigration. New York: Oxford University Press.

Ceva E and Rossi E, eds (2012) Justice, legitimacy, and diversity: Political authority between realism and moralism. London: Routledge.

Christiano T (2008) Immigration, political community, and cosmopolitanism. San Diego Law Review 45: 933-961.

Dewey J (1938) Logic: The theory of inquiry. New York: Henry Holt and Company. 
Dewey J (2012) The public and its problems: An essay in political inquiry. University Park: Penn State Press.

Erman E and Möller N (2015) Political Legitimacy in the Real Normative World: the Priority of Morality and the Autonomy of the Political. British Journal of Political Science 45(1): 2015-233.

Fine $S$ (2013) The ethics of immigration: Self-determination and the right to exclude. Philosophy Compass 8(3): 254-268.

Foucault M (1991) Polemics, politics, and problematisations: an interview. In Rabinow D, ed The Foucault Reader. New York: Penguin: 381-390.

Fox PD (2013) International asylum and boat people: The Tampa affair and Australia's 'Pacific solution'. Maryland Journal Of International Law 5(1): 356-373.

Galston W (2010) Realism in political theory. European Journal of Political Theory 9(4): 385-411.

Geuss R (2008) Philosophy and real politics. Princeton: Princeton University Press.

Gibney M (2004) The ethics and politics of asylum: Liberal democracy and the response to refugees. Cambridge: Cambridge University Press.

Haddad E (2008) The external dimension of EU refugee policy: A new approach to asylum?'. Government and Opposition 43(2): 190-205.

Hall B (2013) Minister wants boat people called illegals. Sydney Morning Herald 19 October. Available at: http://www.smh.com.au/federal-politics/politicalnews/minister-wants-boat-people-called-illegals-20131019-2vtl0.html (accessed 20 August 2014).

Hall E (2013) Bernard Williams and the basic legitimation demand: A defence. Political Studies online first: 13 September 2013 DOI: 10.1111/1467-9248.12070.

Howard J (2003) To deter and deny: Australia and the interdiction of asylum seekers. Refuge 21(4): 35-51.

Hyndman J and Macdonald M (2001) Deliberation and resecuritization: Australia, asylum-seekers and the normative limits of the Copenhagen school. Australian Journal of Political Science 46(2): 281-295.

Little A (2012) Political action, error and failure: The epistemological limits of complexity. Political Studies 60(1): 3-19.

Little A (2015) Reconstituting realism: Feasibility, utopia and epistemological imperfection. Contemporary Political Theory. Epub prior to publication 10 February 2015. DOI:10.1057/cpt.2014.55.

Macdonald T and Ronzoni M (2012) Introduction: The idea of global political justice. Critical Review of International Social and Political Philosophy 15(5): 521-533.

Miller D (2010) Why immigration controls are not coercive: A reply to Arash Abizadeh. Political Theory 38(1): 111-120.

Miller D (2013) Justice for earthlings: Essays in political philosophy. Cambridge: Cambridge University Press.

Mountz A (2008) Another brick in the wall? Neo-refoulement and the externalization of asylum by Australia and Europe. Government and Opposition 43(2): 249-270.

Nine C (2008) The moral arbitrariness of state borders: Against Beitz. Contemporary Political Theory 7(3): 259-279.

Philp M (2010) What is to be done? Political theory and political realism. European Journal of Political Theory 9(4): 466-484.

Risse M (2008) On the morality of immigration. Ethics and International Affairs 22(1): 25-33.

Rossi E and Sleat M (2014) Realism in normative political theory. Philosophy Compass 9(10): 689-701. 
Sen A (2006) What do we want from a theory of justice?. The Journal of Philosophy 103(5): 215-238.

Sigwart H (2013) The logic of legitimacy: Ethics in political realism. The Review of Politics 75(3): 407-432.

Simmons AJ (2010) Ideal and nonideal theory. Philosophy \& Public Affairs 38(1): 5-36.

Sleat M (2014) Legitimacy in realist thought: between moralism and realpolitik. Political Theory 42(3): 314-337.

Stemplowska Z (2008) What's ideal about ideal theory? Social Theory and Practice 34(3): 319-40.

Stilz A (2011) Nations, states, and territory. Ethics 121(3): 572-601.

Valentini L (2012) Ideal versus non-ideal theory: A conceptual map. Philosophy Compass 7(9): 654-664.

Wellman C (2008) Immigration and Freedom of Association. Ethics 119(1): 109-141. Williams B (2005) In the beginning was the deed. Princeton: Princeton University Press. 


\section{University Library}

\section{- M M N E R VA A gateway to Melbourne's research publications}

Minerva Access is the Institutional Repository of The University of Melbourne

Author/s:

Little, A;Macdonald, T

Title:

Introduction to special issue: Real-world justice and international migration

Date:

2015-10-01

Citation:

Little, A. \& Macdonald, T. (2015). Introduction to special issue: Real-world justice and international migration. European Journal of Political theory, 14 (4), pp.381-390. https:// doi.org/10.1177/1474885115584832.

Persistent Link:

http://hdl.handle.net/11343/292058 